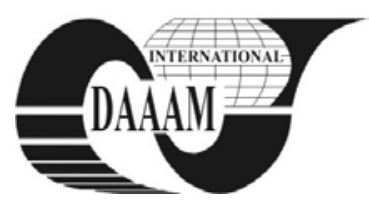

\title{
TRUST AND SOCIAL CAPITAL IN THE VIRTUAL ORGANIZATION
}

\author{
POPA, D[iana] M[ariana] \& NICA COTET, G[abriela] B[eatrice]
}

\begin{abstract}
We argue that in virtual organizations trust and social capital are the bases for successful cooperation and that elements of trust theories developed in the offline work environment, at the micro-sociological level, can be used to explain cooperation in the virtual organization, but the proportions in which these elements matter are different than in the offline environment. Competence matters in the evaluation of the degree in which one can trust a virtual partner to do his job correctly, but this not sufficient and familiarity with that person, found in the social relationship, is more important for a successful cooperation. To demonstrate this we conducted a case study using a comparative approach between members of a virtual organization and of different non-virtual organizations.
\end{abstract}

Key words: virtual, work, trust, social capital

\section{INTRODUCTION}

We see the virtual organization as a virtual product whose development was facilitated by the globalization of the virtual communication process. We choose the knowledge based virtual organization as the framework for our theory and we consider it has the following characteristics: it is a network of (geographically dispersed) specialists who share the same professional field, who have high and complementary competences, and who come together using virtual communication for knowledge creation and sharing in order to create competitive alliances. Because this type of organization is weakly regulated in terms of the cooperation process, we argue that the main base for interactions in this context is interpersonal trust, developed in time between partners.

For Cook et al. (2005) the interdependent reciprocal interests developed in an ongoing interaction are key elements in trust development. Trust is a characteristic of the social relationship, it is based on familiarity.

We therefore use the following analytical elements of trust:

- the evaluation of the other person's competences and motivations (Cook et al. 2005)

- Reputation (Putnam, 1994), (Yamagishi et al. 2003)

- Familiarity (Lewicki, R. \& Bunker, B. 1996) / ongoing interactions (Granovetter, 1992), (Cook et al. 2005)

\section{RESEARCH METHODOLOGY}

Using an online survey of 39 questions we compared perspectives about the cooperation process of people working in non-virtual organizations (meaning organizations that use virtual communication only second to face to face communication) and members of an European knowledge based virtual organization, in the engineering field. We received a number of 67 answers from members of non-virtual organizations from Romania, Netherland and France, from the university and non-governamental area, therefore constituting a multicultural comparison group and 28 answers from the virtual organizations members. This answers constituted our comparative analysis (using SPSS - Statistical Package for the Social Sciences) basis for the motivation and formation of trust and social capital in the cooperation process inside the virtual work environment. Respondents were asked to have in mind their cooperation in the virtual environment when answering the questions.

\section{FINDINGS}

When asked to choose between a a partner with whom they had a good collaboration in the past and a new partner whom they do not know personally, but who has more competences for the project involved, more than three quarters of the members of the virtual organization $(82,1 \%)$ choose the old partner, whereas less than half (40\%) of the members of nonvirtual organizations made the same choice (Table 1.). When asked in an open question to motivate their choice, virtual organization members mentioned: "trust", "confidence", "declared competences vs. attested competences", "I know his work", "why introduce uncertainty due to work experience”, "I know what to expect from him" etc. The most frequent argument of members of non-virtual organizations in favour on the new partner was "better competences for the project".

\begin{tabular}{|c|c|c|c|}
\hline \multicolumn{2}{|l|}{$\%$ within Status } & \multicolumn{2}{|l|}{ Status } \\
\hline $\begin{array}{l}\text { If you had to choose } \\
\text { between a partner with }\end{array}$ & $\begin{array}{l}\text { New } \\
\text { partner }\end{array}$ & \begin{tabular}{|c|}
$\begin{array}{l}\text { Virtual } \\
\text { organization } \\
\text { member }\end{array}$ \\
$10,7 \%$ \\
\end{tabular} & $\begin{array}{l}\text { Non-virtual } \\
\text { organization } \\
\text { member }\end{array}$ \\
\hline $\begin{array}{l}\text { whom you had a good } \\
\text { collaboration in the past }\end{array}$ & $\begin{array}{l}\text { Old } \\
\text { partner }\end{array}$ & $82,1 \%$ & $40,0 \%$ \\
\hline $\begin{array}{l}\text { and a new partner who } \\
\text { you do not know } \\
\text { personally, but who has } \\
\text { more competences for } \\
\text { the project involved, who } \\
\text { would you chose? }\end{array}$ & $\begin{array}{l}\text { I do not } \\
\text { know }\end{array}$ & $7,1 \%$ & $18,2 \%$ \\
\hline \multicolumn{2}{|l|}{ Total } & $100,0 \%$ & $100,0 \%$ \\
\hline
\end{tabular}

Tab 1. Familiarity vs. Competence

$85,7 \%$ of virtual organization members think that "it takes a long time to get to know someone before you are able to work well together" while $70,9 \%$ of non-virtual organization members think that "you don't need to know people well in order to work efficiently with them" (Table 2.). These results confirm that cooperation predominantly using virtual communication is based on familiarity development. Familiarity can refer to coming to know the other's true competences (as an answer to the open question mentioned above suggests, actual competences can be different from claimed competences), to coming to know his communication patterns and to coming to develop a personal relationship in time. A succesfull collaboration therefore needs repeated 
interactions, which, if positive, lead to the formation of familiarity based trust.

\begin{tabular}{|c|c|c|c|}
\hline \multirow{2}{*}{\multicolumn{2}{|c|}{$\%$ within Status }} & \multirow{2}{*}{\multicolumn{2}{|c|}{ Status }} \\
\hline & & & \\
\hline \multirow{2}{*}{$\begin{array}{l}\text { Think about } \\
\text { your } \\
\text { collaborators in } \\
\text { the virtual } \\
\text { organization/en } \\
\text { vironment. } \\
\text { Choose the } \\
\text { statement } \\
\text { which is true } \\
\text { for you. }\end{array}$} & \begin{tabular}{|l} 
It takes a long time \\
to get to know \\
someone before \\
you are able to \\
work well together \\
\end{tabular} & $85,7 \%$ & $29,1 \%$ \\
\hline & $\begin{array}{l}\text { You don't need to } \\
\text { know people well } \\
\text { in order to work } \\
\text { efficiently with } \\
\text { them }\end{array}$ & $14,3 \%$ & $70,9 \%$ \\
\hline \multicolumn{2}{|l|}{ Total } & $100,0 \%$ & $100,0 \%$ \\
\hline
\end{tabular}

Tab. 2 Familiarity importance

When explicitly asked why they trust their collaborators from the virtual network, the most 3 frequent answers of members of the virtual organization were (Table 3.): passed collaboration in the offline environment $(32,1 \%)$ or in the online environment $(28,6 \%)$ or a good personal/friendship relation (28,6\%). We see that professional reputation and legal contracts are not part of the motivations of trust in predominantly virtual work environments.

\begin{tabular}{|l|l|l|l|}
\hline \multirow{2}{*}{ \% within Status } & \multicolumn{2}{|c|}{ Status } \\
\cline { 3 - 4 } & $\begin{array}{l}\text { Virtual } \\
\text { organizatio } \\
\text { n member }\end{array}$ & $\begin{array}{l}\text { Non-virtual } \\
\text { organizatio } \\
\text { n member }\end{array}$ \\
\hline $\begin{array}{l}\text { You trust your } \\
\text { partner from } \\
\text { the virtual } \\
\text { network/enviro } \\
\text { nment because }\end{array}$ & $\begin{array}{l}\text { You collaborated } \\
\text { well with him in } \\
\text { the past in the } \\
\text { offline } \\
\text { environment }\end{array}$ & $32,1 \%$ & $29,1 \%$ \\
\cline { 2 - 4 } & $\begin{array}{l}\text { You collaborated } \\
\text { well with him in } \\
\text { the past inside the } \\
\text { virtual network }\end{array}$ & $28,6 \%$ & $10,9 \%$ \\
\cline { 2 - 4 } & $\begin{array}{l}\text { He has a good } \\
\text { professional } \\
\text { reputation }\end{array}$ & $0 \%$ & $23,6 \%$ \\
\cline { 2 - 4 } & $\begin{array}{l}\text { He was } \\
\text { recommended to } \\
\text { you by someone } \\
\text { else you trust }\end{array}$ & $10,7 \%$ & $18,2 \%$ \\
\cline { 2 - 4 } & $\begin{array}{l}\text { You have a good } \\
\text { personal/friendship } \\
\text { relation with him }\end{array}$ & $28,6 \%$ & $3,6 \%$ \\
\hline $\begin{array}{l}\text { You have a legal, } \\
\text { written contract }\end{array}$ & $0 \%$ & $14,5 \%$ \\
\hline Total & \begin{tabular}{ll}
$100,0 \%$ \\
\hline
\end{tabular} & & \\
\hline
\end{tabular}

Tab 3. Explicit Motivation for Trust

On the other hand, in predominantly offline work environments, professional reputation $(23,6 \%)$ and legal contracts $(14,5)$ play a greater role and the personal relation is much less important $(3,6 \%)$ in the motivation of trusting a collaborator. We can see reputation both as evidence of attested competence and past positive behaviuor, but also as an intention of a person living up to expectations in order to encourage others to cooperate with him in the future (Cook et al.,2005). We must mention here that in the literature over trust, legal contracts and trust are seen as antithetical, meaning that when cooperation is based on written contracts (seen as external guarantees against non-opportunistic behaviour) we cannot talk about trust.

Passed collaboration (whether online and offline) means also familiarity, and shows that trust is a dynamic process, meaning it is build in time through active processes of interaction. This leads to reciprocal knowledge between collaborators.

\section{CONCLUSIONS}

Comparing the results between members of virtual organization and members of non-virtual organizations we can see clear differences between the two groups. As we stated in the introduction, this does not mean competences are not important in the virtual organization. If a collaborator does not have the required competences for fulfilling a certain task, than he will not be chosen to fulfil that task (as Cook et al. 2005 says "trust is specific"). If I lend you my car and I trust you will return it doesn't mean I will trust you to do a task in a work project for which you do not have the required competences. On the other hand, there are many people who might have the required competences for a certain task. But in the virtual work environment, where risk and uncertainty are high, individuals will more likely choose people with whom they worked before, whom they've learned to trust and with whom they possibly developed a personal relationship. This personal relation must not always mean friendship. Granovetter (1992) has long popularized the idea of the benefits of weak ties (of connections between people outside one's close group) and Putnam (1994) also showed how social capital can be beneficial to both individual and society as a whole.

In a dynamic work environment, such as the virtual one, where uncertainty is high due to lack of permanent contact and lack of institutional arrangements for the regulation of interaction, trust is the alternative mechanism for assuring a successful and reciprocal beneficial cooperation. This alternative is valid in offline environments (as Cook et al.,2005; Yamagishi, T. et al., 2003 have shown). But as we have seen, trust in this environment refers more to the personal side on the evaluation of the other, then on the professional side.

\section{LIMITATIONS AND FUTURE RESEARCH PLANS}

We acknowledge the limitations of our research due to the small number of respondents included in our study. However, we consider the selected case study to be representative for knowledge based virtual organizations, based on literature definitions and characteristics. We intend to extend our study to more examples of virtual organizations, in order to test the strength of our conclusions: that cooperation in the virtual knowledge based organization is based on trust.

\section{REFERENCES}

Cook, K.; Hardin, R.; Levi, M. (2005). Cooperation without trust?, Volume IX in The Russell Sage Foundation Series On Trust, Russell Sage Foundation, New York.

Granovetter, M.; Swedberg, R. (1992). The Sociology of economic life, Westview Press Inc, ISBN 0-8133-1032-6

Lewicki, R., Bunker, B. (1996): Developing and maintaining trust in work relationships, in Kramer, R.; Tyler, R. (Ed.): Trust in organizations. Sage Publications, London

Putnam, R. (1994): Making Democracy Work. Civic Traditions In Modern Italy, Princeton University Press, Princeton, New Jersey, ISBN:978-0691037387

Yamagishi, T., et al. (2003). Solving Lemons Problem with Reputation: An Experimental Study of Online Trading Working paper CEFOM/21. Sapporo, Japan: Hokkaido University. 